\title{
Impact of the Somatotrope Growth Hormone (GH)/Insulin-Like Growth Factor 1 (IGF-1) Axis Upon Thymus Function: Pharmacological Implica- tions in Regeneration of Immune Functions
}

\author{
Lindsay Goffinet, Marie Mottet, Hamid Kermani, Chantal Renard-Charlet, Vincent Geenen* and \\ Henri J. Martens
}

University of Liege Center of Immunoendocrinology (CIL), Institute of Pathology CHU-B23, B-4000 Liege-Sart Tilman, Belgium

\begin{abstract}
The thymus is the central lymphoid structure where T-cell differentiation takes place, and a crucial organ for the maintenance of homeostasis in the immune system. Thymopoiesis includes intrathymic proliferation of T-cell precursors, selection and output of both self-tolerant and competent effector $\mathrm{T}$ cells, as well as of natural regulatory $\mathrm{T}$ cells (nTreg). In the crosstalk between the neuroendocrine and immune systems, peptide hormones have been more and more implicated in immunomodulation for the last thirty years. The somatotrope growth hormone $(\mathrm{GH}) /$ insulin-like growth factor-1 (IGF-1) axis in particular has been repeatedly shown to play a major regulatory role upon thymus function and T-cell development. This review will focus on the important thymotropic properties of the somatotrope GH/IGF-1 axis, and will try to discriminate these properties in function of the endocrine or paracrine/autocrine pathways involved in their mediation. Most importantly, in light of an increasing number of recent studies, GH and IGF-1 now appear as novel therapeutic agents that could be used for enhancing thymopoiesis in different cases of immune deficiencies, including aging-related immune dysfunction.
\end{abstract}

Keywords: Thymus, growth hormone (GH), insulin-like growth factors (IGFs), HIV, growth hormone deficiency (GHD), Chagas disease.

\section{GENERAL INTRODUCTION}

The thymus is now considered as a crucial organ for maintenance of immune system homeostasis and the central lymphoid organ where occurs the generation of self-tolerant and competent naive $\mathrm{T}$ cells, as well as self-antigen specific natural Treg cells $[1,2]$. However, for a long time, the thymus has been regarded as an endocrine gland. In addition, the thymus now appears as a privileged site where the endocrine and immune systems intimately interact.

A permanent crosstalk exists between the neuroendocrine and immune systems [3-6]. In addition to the strong modulation of immunity by glucocorticoids and sexual steroids, other hormones have been more and more involved in immunomodulation. Indeed, the somatotrope GH/IGF-1 axis, as well as prolactin and thyroid hormones [7], were shown to play an important regulatory role in T-cell development [810].

$\mathrm{GH}$ is mainly synthesised in the anterior pituitary gland but can also be produced by immune cells [11, 12]. GH has several biological actions in the immune system including regulation of thymopoiesis and T-cell development [13]. Nevertheless, it is uneasy to distinguish whether the thymotropic effects of $\mathrm{GH}$ are direct or mediated by IGF-1, as most

\footnotetext{
*Address correspondence to this author at the University of Liege Center of Immunoendocrinology (CIL), Institute of Pathology CHU-B23, B-4000 Liege-Sart Tilman, Belgium; Tel: +32 436625 50; Fax: +32 436698 59; E-mail: vgeenen@ulg.ac.be
}

of GH effects are driven by induction of IGF-1 and as IGF-1 has also been described as an endogenous factor in the thymic microenvironment [12]. The evolution of the research field has brought new insights that justify an overview update as some ancient conclusions about absence of GH receptor on human differentiating $\mathrm{T}$ cells, or the lack of effect of $\mathrm{GH}$ administration on human thymopoiesis, have been recently revisited. Finally, from the data of recent studies, it has been proposed that GH and IGF-1 could be novel therapeutic agents able to enhance thymopoiesis in immunodeficient individuals [14-16].

\section{The Thymus}

For a long time, the thymus function remained very obscure. In 1961, Jacques F.A.P. Miller demonstrated the importance of the thymus in the immune system by removing the thymus from three day-old mice, and observing thereafter the deficiency of a lymphocyte population, the thymusdependent lymphocytes or T lymphocytes [17]. Today, the thymus is still essentially considered as the organ responsible for the differentiation and the maturation of $\mathrm{T}$ cells, as well as of the natural Treg cells.

\section{Embryology of the Thymus}

In human embryogenesis, around 7 weeks, connections between the two parts of thymus gland and the pharynx disappear and these 2 parts migrate to inferior and ventral position to the developing thyroid. Then, they fuse to form a single, bilobate thymus gland. The cortex and medulla become 
well differentiated at 12 weeks. Shortly after, the thymus is infiltrated by lymphocytes derived from stem cells in the yolk sac, omentum and liver, and the organ reachs its final location in the anterior superior mediastinum in front of the heart, behind the sternum. In the $16^{\text {th }}$ week, the thymus is fully developed. The thymus increases in size from birth, where it is highly active until puberty. At that time, the thymus then undergoes a very slow involution, i.e. an agedependent progressive decrease of the thymus mass $[18,19]$.

During mouse embryogenesis, the thymus epithelium derives from the single endodermal layer of the third pharyngeal pouch only. This process depends on interactions with the surrounding neural crest-derived mesenchyme and occurs between embryonic day (E) 10.5 and E11.5 [20, 21]. At more or less E12, lymphocyte progenitors colonized the immature thymus, which is, at this stage, mainly composed of thymic epithelial cells (TEC) progenitors without cortical and medullary definition $[22,23]$. Subsequently, TEC progenitors will differentiate and lead to the construction of distinct cortical and medullary TEC subsets that are the major constituents of thymic stroma [23]. Maintaining TEC differentiation is influenced by thymocyte-derived signals [24]. This interdependence of thymocyte and TEC populations has been called thymic crosstalk [25]. In addition to thymocytes, other non-hematopoietic stromal elements, such as fibroblasts and endothelial cells, and distinct bone marrow-derived dendritic cells (DC) and macrophages also contribute to the final thymic architecture [26]. Thymic mesenchymatous cells also contribute to various structures of the thymus such as capsule or vasculature [27-30].

\section{Thymic T-Cell Development}

Like all hematopoietic cells, T lymphocytes originate from bone-marrow-resident hematopoietic stem cells (HSC). HSC will generate all blood lineages within the marrow whereas T-cell development essentially takes place in the thymus. The thymus microenvironment is the unique organ that has the capacity to support T-lineage restriction and differentiation [31]. T-cell precursors from fetal liver then bone marrow migrate to the thymus in small numbers through the blood vessels in the cortico-medullary junction. The course of these precursors through the thymus is schematized in the Fig. (1) with the principal differentiative events. At this moment, the immature thymocyte does not express surface molecules such as the T-cell receptor for antigen (TCR), which is responsible for recognizing antigens presented by

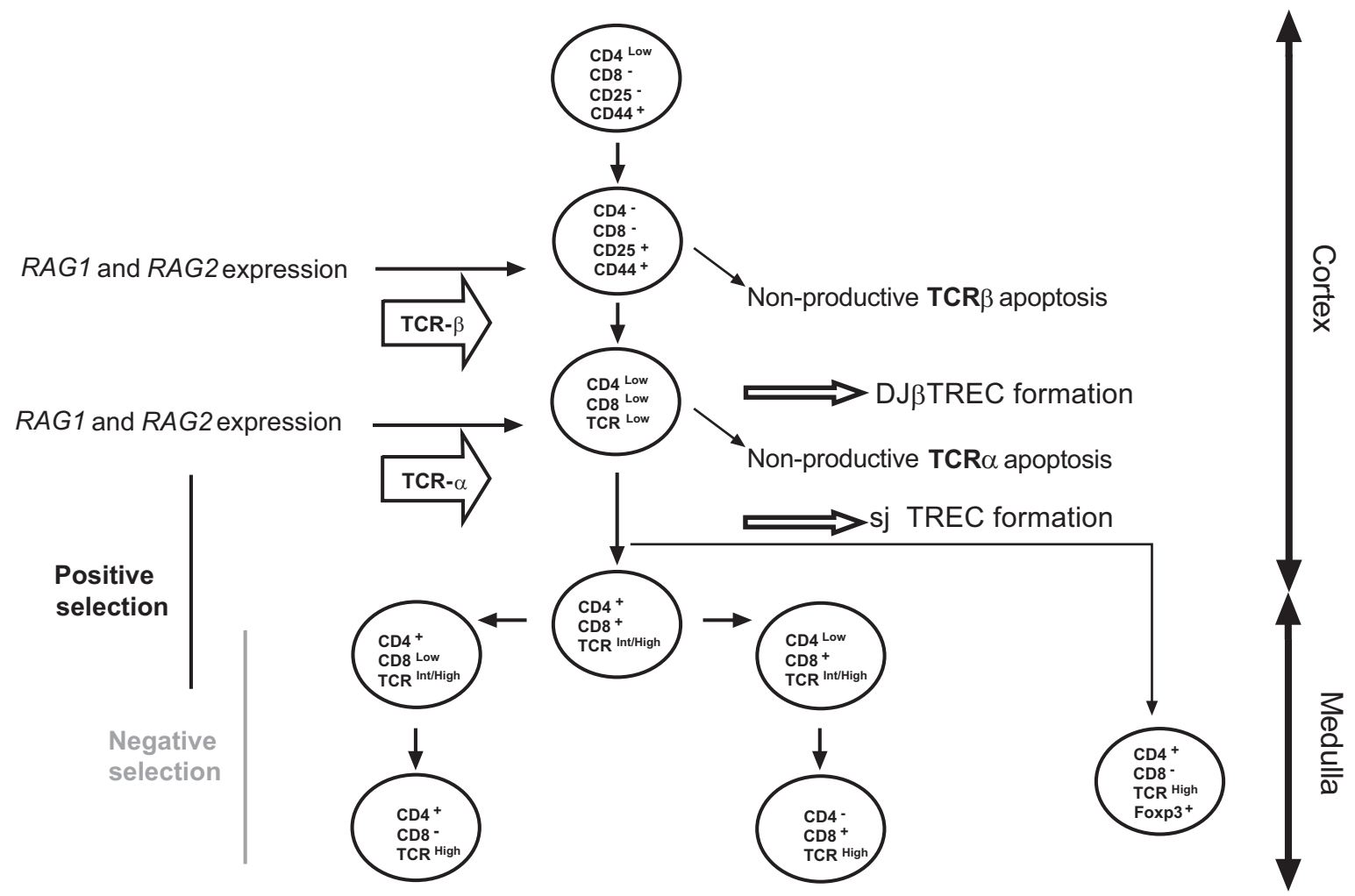

Fig. (1). Stages of thymocyte differentiation: Pre-T cells entering the thymus express no CD8 and weakly CD4. They also lack CD25, but express CD44. They acquire CD25 while CD4 becomes undetectable. These DN cells begin to co-express CD4 and CD8 giving the unique thymic population of DP cells and activate the TCR rearrangement by expression of the RAG enzymes that first recombine the $\beta$ locus of TCR genes. The non-productive rearrangement leads to cell death by apoptosis. Recombination by-products are the DJ $\beta$ TREC, followed by the VD $\beta$ TREC (not shown in the diagram). A second phase of recombination concerns the a locus and begins with the excision follows. This phase begins by the excision of the $\delta$ locus and this excision circle is usually named sjTREC, while the last excision circles resulting from $\alpha$ locus productive rearrangement between the $\mathrm{V} \alpha$ and $\mathrm{J} \alpha$ regions are often called cjTREC (not shown in the diagram). The positive selection process of competent $\mathrm{T}$ cells starts in the cortex. At this stage some cells deviate to the lineage of natural regulatory $\mathrm{T}$ cells (nTreg, CD4+CD25+Foxp3+), a selection process that will continue throughout the late differentiation stages. At the same time, the pre-T cells leave the cortex and enter the thymus medulla and fully co-express CD4 and CD8. These DP cells with a complete TCR go through the positive and negative selection processes to mature as single positive CD4, CD8 before leaving the thymus. 
proteins of the major histocompatibility complex (MHC), or the cluster differentiation (CD) markers CD4 and CD8, which are co-receptors of TCR [32]. Other markers such as $\mathrm{CD} 25, \mathrm{CD} 3$ and CD44 are very useful to define stages of intrathymic T-cell differentiation. CD3 forms with TCR a multimolecular complex that promotes signal transduction pathways necessary for TCR-driven T-cell activation. CD25 is the $\alpha$-chain of the interleukin-2 (IL-2) receptor. The proteoglycan CD44 is a receptor for hyaluronic acid, and to lesser extent for fibronectin and collagen. In addition to be $\mathrm{CD}^{-} \mathrm{CD}^{-} \mathrm{TCR}^{-}$, the immature thymocytes recently migrated in the thymus are also $\mathrm{CD} 25^{\circ} \mathrm{CD} 44^{-} \mathrm{CD} 3^{-}$. During their differentiation, these precursor cells first acquire CD44 on the cell membrane following by $\mathrm{CD} 25$, becoming $\mathrm{CD} 44^{+} \mathrm{CD} 25^{+}$, and then sequentially lose CD44 and CD25. They represent $3-5 \%$ of total thymocytes. Thymocyte maturation then progresses with the acquisition of both CD4 and CD8 markers, generating the so-called $\mathrm{CD} 4^{+} \mathrm{CD}^{+}$double-positive thymocytes (DP). These cells are the most common in the thymus, and represent $75-85 \%$ of the whole thymocyte population in adult. At this stage, DP cells undergo TCR gene rearrangement. In differentiation of $\alpha \beta \mathrm{T}$ cells, the TCR $\beta$-chainrelated genes first rearrange followed by the TCR $\alpha$-chain genes. Thymocytes that do not undergo productive TCR gene rearrangements die by apoptosis. By contrast, those expressing productive TCR will be able to interact with endogenous peptides presented by MHC proteins, expressed by thymic microenvironmental cells. This interaction is crucial for normal thymocyte differentiation and determines both positive and negative selection. Positively selected $\mathrm{T}$ cells escape from programmed cell death and become mature $\mathrm{CD}^{+}$or $\mathrm{CD}^{+}$single positive (SP) cells. These single positive cells represent $12-15 \%$ of total thymocytes and will leave the thymus to yield the large majority of the T-cell repertoire in the periphery. Thymic $\mathrm{T}$ cells bearing a TCR with high affinity for the complex MHC/self-peptides are negatively selected and die by apoptosis [26, 32]. Some $\mathrm{CD}^{+}$cells express CD25 and the transcription factor FoxP3 that controls the differentiation of natural $\mathrm{CD} 4{ }^{+} \mathrm{CD} 25^{+}$Treg cells. In addition to CD25 and Foxp3, natural Treg cells express CTLA-4, GITR and lymphoid homing receptors such as CD103, CD62L. Natural Treg cells play a crucial role in central tolerance and in preventing autoimmune diseases by down regulating any expanded peripheral lymphocyte pool. Studies showed that they suppress the function of effector $\mathrm{CD}^{+} \mathrm{CD} 25^{-} \mathrm{T}$ cells, cytotoxic $\mathrm{CD}^{+} \mathrm{T}$ cells, NK cells and $\mathrm{B}$ cells. This suppression depends both on cell-contacts and on immunosuppressive cytokines such as TGF- $\beta$ and IL-10. Therefore, they are key regulators in the control of autoimmunity [2, 33]. Intrathymic T-cell differentiation is supported by interaction between thymocytes and various components of the thymic microenvironment including TEC, macrophages, dendritic cells, fibroblasts, and extracellular matrix components [26, 34]. Moreover, recent studies have shown that the cytokine IL-7 synthesized by TEC is crucial for supporting thymocyte differentiation [35].

Until 1995, the thymus function was thought to decline in adult. However, through quantification of $\mathrm{T}$-cell receptor rearrangement excision circles (TREC), the adult thymus was shown to be active late in life for delivering mature naïve T lymphocytes to the periphery [36-38]. During V(D)J rearrangement of the TCR, the recombination-activating (RAG) enzymes RAG1 and RAG2 recognize the recombination signal sequences (RSS) that flank the coding segments. TREC correspond to the circularised DNA located between the two RSS. Different types of TREC are generated such as signal-joint (sj) TREC and DJ $\beta$-TREC. These TREC are stable and not duplicated during mitosis and, therefore, are diluted out during peripheral proliferation. Thus, TREC represent a reliable technique to assess thymic output of naïve $\mathrm{T}$ cells [39-42]. For practical reasons, sjTREC are the most useful for the overall thymic output as they are formed in $70 \%$ of $\alpha \beta \mathrm{T}$ cells, while the sj/D $\beta$ TREC ratio reflects the level of intrathymic $\mathrm{T}$ cell proliferation. Other TREC are either too diverse to be easily measured, or generated in minor T-cell subsets [43].

\section{The Somatotrope GH/IGF-1 Axis and Thymus Function in Rodents}

$\mathrm{GH}$ is a hormone that exerts its effects through binding to the $\mathrm{GH}$ receptor (GHR), a type 1 cytokine receptor [44], which is the first cloned member of this family and which shares a single transmembrane domain structure with other receptors including the prolactin receptor, and many other type 1 cytokine proteins [45]. The GH signal transduction is mediated by the activation of the Janus Kinase (JAK)/Signal Transducer and Activator of Transcription (STAT) pathway [46]. GH binding to the GHR causes receptor dimerization and leads to the activation of JAK2 tyrosine kinase. The activity of JAK2 mediates many of the downstream responses to $\mathrm{GH}$ through phosphorylation/dimerization of STAT5, mitogen-activated protein (MAP) kinases, other kinase cascades and molecules involved in metabolism like insulin receptor substrate 1 (IRS-1) [47, 48]. Factors like suppressor of cytokine signaling (SOCS) and the protein tyrosine phosphatase SHP-1 appear to play a role in the down regulation of signalling by $\mathrm{GH}$ and cytokines [49].

The somatotroph cells located in anterior pituitary gland secretes GH under the influence of growth hormone releasing hormone (GHRH) and ghrelin, whereas somatostatin inhibits GH secretion [50-53]. Ghrelin is an endogenous ligand for the GH secretagogue receptor (GHS-R). It is mainly secreted from the stomach but also by other organs such as the brain, pituitary, placenta, ovaries, testes, kidneys, small intestine, pancreas and lungs, and fasting stimulates ghrelin secretion $[52,53]$. $\mathrm{GH}$ is also produced in many extrapituitary sites, including cells of the immune system [11, 54]. Indeed, studies have demonstrated the presence of $G h$ mRNA and corresponding protein in rat thymocytes $[55,56]$, and GHRH stimulates $G h$ expression by these cells [57]. However, studies in dwarf mice have evidenced that $\mathrm{GH}$ expression by pre-T and mature $\mathrm{T}$ cells do not fully depend on Pit-1, which is the main transcription factor for $G h$ expression in the pituitary $[58,59]$. Therefore, the regulation of $\mathrm{GH}$ secretion may not be the same in lymphocytes and in the endocrine system.

In 1974 , it was shown that $\mathrm{GH}$ is able to bind to thymocytes [60]. GH receptor (GHR) expression in murine thymocytes is particulary detected in the DN immature subset [61]. These data indicate that direct effects of $\mathrm{GH}$ on thymocytes might precede events related to the further selection of the T- 
cell repertoire. Additionally, in situ hybridization studies in the rat thymus revealed an epithelial labelling for $G h r$ mRNA [62]. These findings suggest that $\mathrm{GH}$ exerts local paracrine/autocrine actions that may be direct or mediated by circulating IGF-1 or by other factors. Therefore, although the functions of $\mathrm{GH}$ and IGF-1 do not overlap entirely, many $\mathrm{GH}$ effects on multiple organs including the thymus and the peripheral immune system could also be mediated through IGF-1 induction. IGF-1 is part of the IGF system, which also includes IGF-2, insulin, six characterized binding proteins (IGFBP-1 through -6) and cell surface receptors that mediate the actions of the ligands (IGF type 1 receptor, insulin receptor, and the IGF type 2 mannose-6-phosphate receptor) [6365]. The IGF type 1 receptor (IGF-1R) is a tyrosine kinase receptor, related to the insulin receptor [66]. The two major pathways activated by the IGF-1R are the MAPK and phosphatidylinositol 3-kinases (PI3-K) pathways [66]. An endpoint of the MAPK pathway is modification of transcription factor activity, such as activation of an ETS-like transcription factor. Serum response factor (SRF) and activator protein 1 (AP-1) contribute to mitogenic signalling by many factors. Phosphorylation of IRS-1 is also involved in IGF-1 signalling, similar to insulin signalling [67].

IGF-1 and -2 are growth-promoting factors regulating cellular survival, proliferation and differentiation [68]. Large amounts of IGF-1 and IGF-2 are present in blood of fetal rodents whereas, in adult rodents, their concentrations are low [69]. In mouse, in combination with GH, IGF accounts for $83 \%$ of postnatal body growth [70]. The cellular responses to both IGF-1 and IGF-2 are mediated by the IGF$1 \mathrm{R}$, and IGF biodisponibility is regulated by the IGF binding proteins [71]. IGF-1 is mainly produced in the liver and participates in the regulation of $\mathrm{GH}$ secretion by the pituitary $[68,72]$. Several studies have shown that murine TEC also express IGF-1 and IGF-1R. In mice, IGF-2 is the dominant thymic member of the family expressed in the thymus during fetal life, while IGF-1 predominates in postnatal [73, and personal observations]. IGF-1R has also been identified on rodent thymocytes [74]. In murine fetal thymic organ cultures, inhibition of IGF-1 by a specific antibody resulted in significant changes in total thymocyte number and subset composition [73]. IGF-1 has also been proposed as a positive thymic regulator based on early observations that age-related thymic involution parallels the decrease in plasma IGF-1 concentrations [75]. At the level of the whole organ, in vivo observations revealed that recombinant GH and IGF-1 accelerates the recovery of $\mathrm{T}$ cells after treatment with cyclosporin A, which causes thymic atrophy, and that IGF-1 is able to induce repopulation of the atrophic thymus [76]. GH is supposed to initiate or to enhance a functional intrathymic circuitry including IGF-1 and its receptor. Administration of IGF-1 enhances the recovery of DP T cells in thymus after dexamethasone treatment in rats [77]. Therefore, IGF-1 is able to directly increase thymic cellularity. Implantation of GH3 cells in aged rats and recombinant IGF-1 supplementation in mice with impaired immune status leads to the recovery of thymic atrophy $[77,78]$. These data may also suggest that IGF-1 is produced by a variety of thymic cells in a paracrine/autocrine fashion independently of $\mathrm{GH}$ regulation. It has also been shown that administration of rhIGF-1 in mice for one to two weeks results in an increase of thymic mass by doubling T-lymphocyte population [79]. This is further evidence showing that treatment with rhIGF-1 increases thymocyte number. Furthermore, in restoration of the thymus, GH is less effective than IGF-1 but the best results are obtained by combination therapy [80]. Recently, it has been evidenced that, in intact thymus, IGF-1 increases peripheral naive and recent thymic emigrant (RTE) whereas, in IGF-1-treated thymectomized mice, no changes were observed in the peripheral T-cell population, suggesting that IGF-1 increases thymic function and thymic output through a sequential increase in thymocyte subset proliferation [81]. A recent study has also demonstrated the importance of IGFBP-4 in thymic development since Igfbp 4 transgenic mice show a significantly reduced thymus [82].

The first evidence showing that $\mathrm{GH}$ is involved in thymic regulation was the involution of the rat thymus observed following hypophysectomy [8]. Then, other studies have confirmed this observation and converging data now firmly indicate that IGF-1 is involved in the effects of $\mathrm{GH}$ in the thymus. GH/IGF-1 could act on numerous thymic functions. Different studies on rodents have shown that the somatotrope axis act on thymocyte number $[83,84]$, on TEC growth [85, 86 ] and on the production by TEC of the chemokines CXCL12 and CCL25 [87, 88].

\section{Effects on Thymocyte Number}

Besides the effect of GH/IGF-1 on thymocytes, several studies evidenced that $\mathrm{GH}$ can modulate proliferation of lymphoid precursors in the bone marrow, therefore increasing the number of potential pre-T cells that will differentiate into the thymus. GH has also been shown to influence hematopoiesis. In vitro, GH directly enhances erythropoiesis [89] and a decrease in splenic hematopoietic progenitor cells is observed in GH-deficient dwarf mice [90]. In addition, GH has been shown to indirectly stimulate granulopoiesis in $v i$ tro through the release of secondary mediators such as IGF-1 [91]. In vivo, $\mathrm{GH}$ exerts significant direct hematopoietic growth-promoting effects and partially counteracts the myelosuppressive effects of azydothymidine [92]. A direct effect of $\mathrm{GH}$ on thymocytes is postulated since these cells expressed both GHR and IGF-1R [61, 74]. The exact mechanism is not yet known, but it has been shown that GH enhances $\mathrm{T}$-cell proliferation in rodents. The implantation in aged rats of pituitary $\mathrm{GH} 3$ cells secreting $\mathrm{GH}$ increases the size of their thymus and increases thymocyte numbers [79]. In $\mathrm{GH}$ - and prolactin-deficient dwarf $\mathrm{DW} / \mathrm{J}$ mice, GH administration increases thymic cell number and T-cell proliferation [93]. Furthermore, multiple studies in snell dwarf mice have suggested that $\mathrm{GH}$ production by the pituitary gland also occurs during the stress response and that $\mathrm{GH}$ and/or IGF-1 might act as antagonists to glucocorticoids [94].

\section{Effects on Thymic Epithelium}

TEC are essential to support T-cell differentiation and selection. A recent study has demonstrated that, in mice, IGF-1 administration leads to an increase of cTEC and mTEC numbers and also to an increase in thymocyte number and proliferation [83]. In addition, IGF-1 stimulates the production of CXCL12 and CCL25 by TEC, which are chemokines 
with an essential role in thymocyte development by regulating directional migration and thymic homing of developing thymocytes [83]. Expanded number of TEC results in increased levels of extracellular matrix elements such as laminin that are important for thymocyte adherence. Under isogenic and xenogenic conditions, GH plays a role in the recirculation of $\mathrm{T}$ lymphocytes. Indeed, recombinant human GH promotes human T-cell transplantation in SCID mice and the murine thymus is colonized by human $\mathrm{T}$ cells. This process is thought to be mediated by adhesion molecules and by the extracellular matrix [95]. Furthermore, addition of GH or IGF-1 in murine TEC cultures increases production of fibronectin and laminin but also enhances expression of their receptors, VLA-5 and VLA-6, which leads to an increase of thymocyte adhesion to cultured TEC [96, 97]. Finally, a study has also demonstrated by in vivo and in vitro (fetal thymic organ cultures) manipulations that IGF-1 stimulates the entrance of T-cell precursors into the thymus [98].

\section{Effects on Cytokines}

In addition, other findings strongly suggest that $\mathrm{GH}$ also influences cytokine production by the thymic microenvironment. Increased cytokine production such as IL- $1 \alpha$, IL-1 $\beta$ and IL-6 due to exogenous GH was first demonstrated in bovine thymic stromal cells [99]. IL-6 production by thymocytes is also upregulated by in vivo injection of GH in ageing animals [100]. In addition, in vivo injection of $\mathrm{GH}$ in ageing animals significantly increases thymulin levels [100]. These enhancing effects of GH on thymulin secretion were directly obtained by treating murine or human primary TEC cultures [87]. These data point to a direct effect of GH upon TEC, improving thymulin production.

Altogether, these data argue for an important role of the GH/IGF-1 axis in regulating normal thymus function and Tcell development even if they are not essential for normal thymus and $\mathrm{T}$ cell function [101].

\section{The Somatotrope GH/IGF-1 Axis and Thymus Function in Humans}

Besides strong evidence that the somatotrope GH/IGF-1 axis affects thymus physiology in animals, several studies led to the same conclusions in humans. Indeed, several studies have shown that GH exerts thymotropic properties in humans, which are either direct or mediated by IGF-1 [102]. In humans, $\mathrm{GH}$ is produced by extra-pituitary sites, including TEC, thymocytes, and peripheral lymphocytes [11, 54, 103]. Initially, via immunocytochemistry and in situ hybridization experiments, intrathymic production of $\mathrm{GH}$ has been revealed in cTEC, in septal cells but not in thymocytes [56]. Nonetheless, several other studies have demonstrated that immunoreactive and biologically $\mathrm{GH}$ is produced by isolated human thymocytes [85]. More recently, by RT-PCR and immunoradiometric assays, GH was shown to be produced and secreted by isolated human thymocytes, as well as by human TEC primary cultures [104]. Like in rodents, the regulation of $\mathrm{GH}$ secretion in lymphocytes differs from the one in the pituitary. Indeed, exogenous IGF-1 did not affect $\mathrm{GH}$ secretion by human lymphocytes, while exogenous hGH was demonstrated to up-regulate hGH secretion in vitro [105]. The biological effects of GH are mediated by recep- tors located in target cells membranes. The binding of GH causes dimerization of its receptor with activation of JAK2 and STAT5 proteins, which is comparable to GH signalling in mice [106]. GHR is expressed by human thymocytes, and this expression is mainly present in immature $\mathrm{CD} 34^{+} \mathrm{CD} 2^{+}$ $\mathrm{CD}^{-} \mathrm{CD}^{-} \mathrm{CD} 8^{-}$triple negative precursors, which display various capacities for differentiation [62]. This finding is in agreement with GHR expression by immature murine thymic cell subsets. However, GHR can also be seen in a minor percentage of mature thymocytes, thus suggesting that GH may act throughout the whole differentiation process [107]. Fig. (2) presents a summarized view of the GHR expression along the differentiating $\mathrm{T}$ cells. Together, these data support a paracrine/autocrine mode of action for $\mathrm{GH}$ in the human thymus although the effects of GH might be partially mediated by IGF- 1 .

Unlike in rodents, IGF-1 and IGF-2 plasma concentrations are high in adult humans $[69,108]$. Little information is available about the variation of their thymic expression during ontogeny, IGF-1 is weakly expressed in TEC after birth [109]. Therefore, the involvement of IGF-1 in the human thymus might differ from the observations in the mouse model. Contrary to IGF-2, IGF-1 plasma concentrations are controlled by GH status [69]. However, some amounts of IGF-1 are also regulated by GH-independent pathways, as evidenced by the presence of significant plasma IGF-1 levels in GHR-deficient humans [110]. In addition to being mainly secreted by the liver and other tissues, there are ample evidence for a local production of IGF-1 in the thymus where this growth factor could act in an autocrine/paracrine way. Receptor activation following binding of IGF-1 and IGF-2 elicits a repertoire of cellular responses including proliferation, and protection of cells from programmed cell death or apoptosis. The two best-characterized pathways associated with IGF-1R activation are the MAPK and PI3-K pathways [111]. The expression of IGF-1 and IGF-1R by thymic T cells has been suggested, since anti-IGF-1R antibodies can block IGF-1 effects on these cells [87, 101]. Later, it has been shown that, in the human thymus, DN thymocytes have the highest level of IGF-1R expression, followed by DP cells, whereas the SP thymocytes express the lowest number of IGF-1R [104]. As for GHR, IGF-1R presence according to differentiation steps of $\mathrm{T}$ cells is represented in Fig. (2). Moreover, the presence of IGF-1R in human TEC has been characterized and IGF-1 stimulates expression of laminin, fibronectin, VLA-5 and VLA-6 by these cells, thus demonstrating the functionality of IGF-1R in human TEC [112]. Like in rodents, several studies have shown that GH/IGF-1 axis exerts its effects on numerous thymic functions such as the proliferation of thymocytes, TEC growth, and TEC production of chemokines like CXCL12 and CCL25.

\section{Effects on Thymocyte Number}

In humans, GH and IGF-1 have also been shown to exert an impact on hematopoiesis. Administration of IGF-1 in patients suffering from Laron syndrome (with GHR deficiency) results in a strong stimulatory effect on erythropoiesis [113]. Accordingly, erythropoiesis, which is impaired in adult GHdeficiency, is stimulated once the patients undergo $\mathrm{GH}$ treatment [114]. Therefore, an effect on pre-T cell number has to be considered, in addition to the potential direct action 


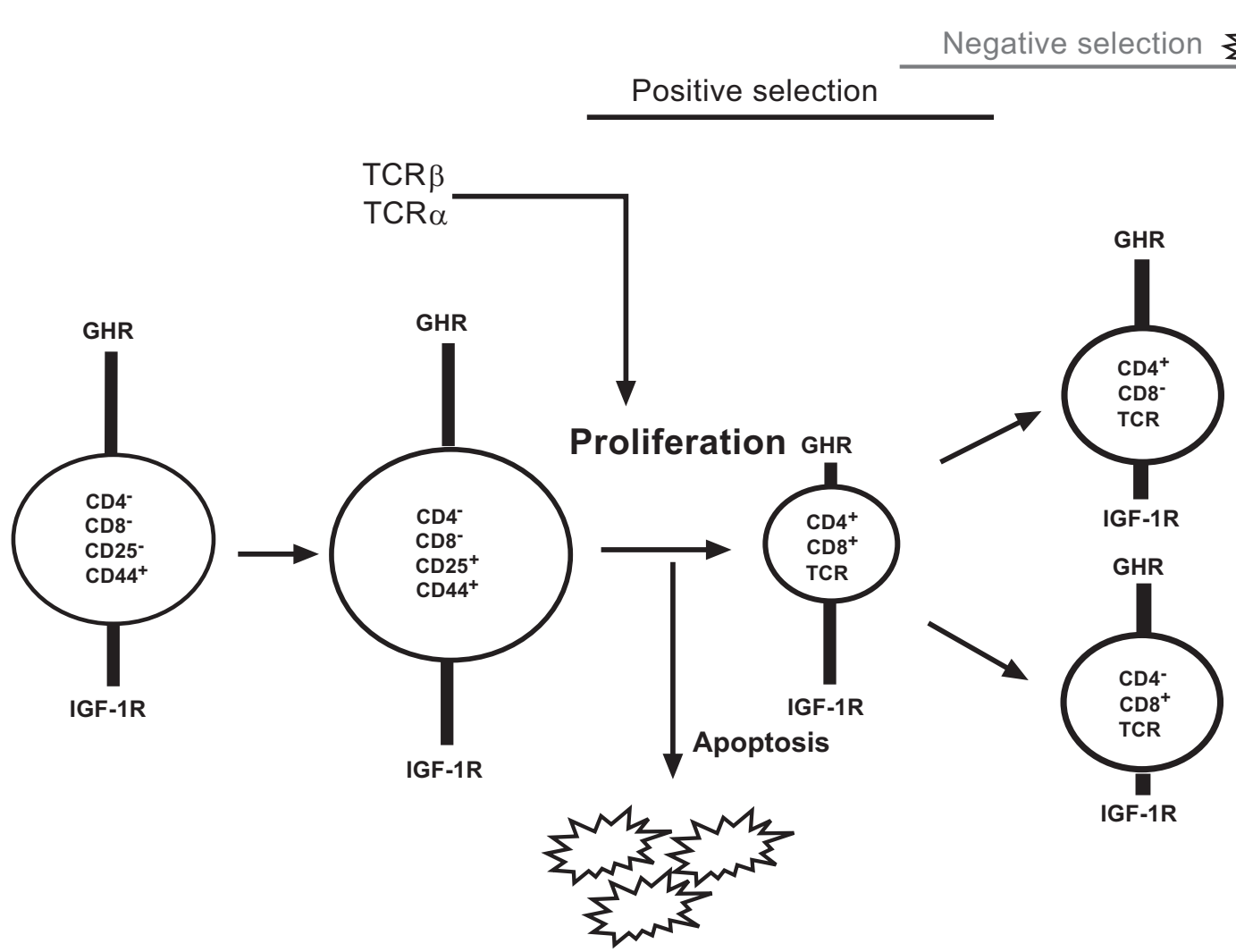

\section{Non productive TCR $\beta$ and TCR $\alpha$}

Fig. (2). GHR and IGF-1R expression: The proliferation and differentiation effect can be differently marked depending on the stage of cell differentiation in the thymus. The size bars reflects the abundance of GH and IGF-1 receptors found on T cell subsets. The pre-T cells during DN stages present the highest level of both GHR and IGF-1R. The proliferation stage where the TCR rearrangement occurs ends with the generation of numerous DP cells with a complete TCR. These cells bear little or no GHR, while IGF-1R were clearly found on rodent cells, but were decreased on human DP cells. Differentiiaon ends with the SP cells with GHR reappearing, mostly on the CD4 subset, and IGF-1R found at a lower level on both CD4 and CD8.

on thymus function. Long-term GH treatment of immunodeficient HIV-infected patients leads to increase in thymic mass, in frequency of circulating TREC within PBMC, and in the number of $\mathrm{CD} 4^{+} \mathrm{T}$ cells [15]. These findings are consistent with animal studies showing that GH is able to stimulate thymopoiesis. Furthermore, these increases of TREC frequency and T-cell gain are correlated to an increase of plasma IGF-1 [15], arguing for a crucial role of IGF-1 in $\mathrm{GH}$-mediated stimulation of thymic T-cell production. Investigation of thymopoiesis in adult GH deficiency (AGHD) has demonstrated that, after GH withdrawal, intrathymic T-cell proliferation and thymic T-cell output decreased whereas resumption of GH treatment led to an increase of thymopoiesis to a level close to the one before withdrawal of $\mathrm{GH}$ treatment [16]. Again, in this study, the close correlation between plasma IGF-1 concentrations and the frequency of sjTREC in PBMC suggests that the thymotropic properties of GH could be mediated by IGF-1 [16]. It should be also noted that the effects of the somatotrope GH/IGF-1 axis on thymocytes might be relayed by other soluble factors like cytokines. Among them, IL-7 is a cytokine essential for $\mathrm{V}(\mathrm{D}) \mathrm{J}$ recombination at the TCR locus, and this cytokine modulates chromatin accessibility for RAG-mediated cleavage. IL-7 is the only known interleukin that promotes T-cell differentiation and so appears to be a candidate in mediating GH/IGF-1 actions upon the thymus $[115,116]$.

\section{Effects on Thymic Epithelium}

An increase in thymic tissue was observed in HIVinfected adults after GH therapy [14]. These data are consistent with previous studies documenting the ability of GH to stimulate thymopoiesis in animals and establishes that $\mathrm{GH}$ also has significant effects on the human immune system. Although the effect on thymic epithelium was not directly investigated, it confirms that GH/IGF-1 axis induces thymotropic properties as shown by thymic hyperplasia detected in acromegaly patients [117].

\section{PHARMACOLOGICAL IMPLICATIONS}

\section{Implications in Immunosenescence}

Immune defences decline with age as evidenced by the increase of infections in elderly. After puberty and with advancing age, the thymic space becomes progressively filled with adipocytes coupled with a dramatic loss of thymocytes leading to a reduction in output of naïve $T$ cells. This process is called thymic adipose involution [56]. The age-related decline in immune functions (immunosenescence, which includes the skewing of CD4/CD8 ratio toward CD8) is partially responsible for the increased prevalence and severity of infectious diseases, and the low efficiency of vaccination in elderly persons $[118,119]$. There has been considerable in- 
terest in using hormone replacement therapy to regenerate the involuted thymus during aging. The possibility that the GH/IGF-1 axis improves thymic functions, including thymocyte proliferation and migration, particularly places these molecules as potential therapeutic agents. Indeed, implantation of GH-producing cells in old rats reverses thymus atrophy [78], and further studies have demonstrated that $\mathrm{GH}$ treatment increased thymic cellularity in aged animals. Consistent results were also obtained with IGF-1 administration. In old animals, enhancement of thymopoiesis was also achieved with IGF-1 [77]. Although GH and IGF-1 increase thymopoiesis in old animals, it is important to note that Tcell production is not restored to the level present in young animals suggesting that there may be limits on the extent to which GH and IGF-1 can improve thymopoiesis in old rodents [98]. Interestingly, treatment of SCID mice with a GH secretagogue (GHS) results in increased thymic cellularity and differentiation, as well as in promoting thymic engraftment in bone marrow transplant [120]. Furthermore, ghrelin, a potent $\mathrm{GH}$ secretagogue, can also promote T-cell output from an aging thymus [121]. Also in primary immunodeficiencies, manipulation of the somatotrope GH/IGF-1 axis offers promising results. As noted above, $\mathrm{GH}$ treatment of AGHD was shown to improve thymus function [16]. Contrary to AGHD however, the GH deficient child presents an intact immune function. So, in case of deficiency, GH could be replaced by other factors allowing a normal function of the immune system [122]. For example, ghrelin can exert $\mathrm{GH}$-like properties at different levels of the immune function [123].

\section{Implications for HIV Infection}

The targeting of the thymus by HIV has been extensively studied. Complex interactions involving inflammatory infiltrates surrounding lymphodepleted thymic epithelium [124], disrupted early $\mathrm{T}$ cell development [40] and increased thymic production of nTreg [125] are currently documented. Treatment of HIV infection treatment dramatically improved with highly active antiretroviral therapy (HAART). However, this therapy causes adverse events, which include metabolic changes termed lipodystrophy. Several mechanisms are underlying lipodystrophy and HIV itself may have a role in its aetiology [126]. Lipodistrophy, which occurs in $83 \%$ of HIV-infected patients with HAART, is associated with alterations in $\mathrm{GH}$ dynamics similar to what is observed in severe AGHD [127]. The idea that GH supplementation of these patients with lipodystrophy might improve the thymusdriven reconstitution of CD4 compartment was therefore tested. Indeed, early studies on GH therapy in HIV patients had limited results. For example, Nguyen et al. have reported that administration of rhGH or rhIGF-1 to patients did not lead to a significant increase in $\mathrm{CD}^{+} \mathrm{T}$ cell numbers [128]. Later, through the use of increasingly widespread of the antiretroviral therapy, the observation of lipodystrophy and its associated GHD leads to discriminate between patients with HAART who are deficient in GH or not. The striking result was that CD4 count, thymus volume, plasmatic IL-7 and RTE were all significantly lower in a group of HIVinfected children with GHD versus GHD negative group [129]. Thereafter, it was shown that thymopoiesis as well as the numbers of $\mathrm{CD}^{+}$RTE cells were increased in middle- aged AIDS patients treated with GH and antiretroviral therapy $[15,130]$. The conclusion is that, coupled to antiretroviral therapy and especially when a GHD is evidenced, GH could be effective to enhance the restoration of a full immune response.

\section{Implications for Chagas Disease}

The effects of GH therapy are currently investigated in another infectious disease, Chagas disease, which is a debilitating inflammatory disease caused by the protozoan parasite Trypanosoma cruzi. In mice infected by T. cruzy, a thymus atrophy, including DP cell depletion [131], and a decrease in $\mathrm{GH}$ production are observed. Indeed, the thymus is a target for numerous infectious diseases including T. cruzi [132] and T. cruzi also affects the hypothalamo-pituitary axis in mice [133]. Demonstration that GH3 cells, a model of $\mathrm{GH}-$ secreting cells, infected by $T$. cruzi have downregulated their Pit-1 expression, and consequently their GH expression, has recently been brought provided [134]. Lately, it was shown that treatment of infected mice with $\mathrm{GH}$ leads to a reduction in the number of blood trypomastigotes, as well as the cardiac tissue parasitism and inflammatory infiltrate suggesting that GH therapy enhances the immune response [135]. In human, decreased CD4 lymphocytes in Chagas patients was described ten years ago [136]. Thymic function appears to be affected in several ways by $T$. cruzi, including the expression of chemokines, extracellular matrix molecules and receptors [137] and disturbing the pre-T cells trafficking, but also the shaping of peripheral $\mathrm{T}$ cell repertoire that reveals changes both in infected mice and human [138-140]. As for HAARTtreated HIV infection, conjonction of thymotropism of pathogen, GH/IGF-1 axis disturbance and correlated effects on $\mathrm{T}$ immune system suggest that $\mathrm{GH}$ can be considered as an immunomodulating substance for boosting the T-cell system and controlling parasite replication, and a combination of GH with anti-infectious drugs could be a new therapeutic strategy to reduce the harmful effects of Chagas disease. However, it should be noted that GH increases CXCL12 expression and pre- $T$ cell migration [88], one of the chemokine augmented after $T$. cruzi infection with proposed negative consequences. Therefore, cautions must be taken before to concluding that $\mathrm{GH}$ treatment would always increment the benefit-cost ratio.

\section{Conclusions and Perspectives}

Accumulating data have evidenced that the hormones of the somatotrope axis, GH and IGF-1, are particularly involved in the interaction between the two systems by enhancing thymus functions especially when they have been compromised by disease, therapy or aging as many studies have shown. It has been repeatedly shown that GH, IGF-1 and their cognate receptors are expressed by immune cells, and that their thymotropic properties most probably involve also autocrine/paracrine mechanisms. Therefore, further investigations of the mechanisms involved in thymotropic effects of the GH/IGF-1 axis may shed light on the treatment and prevention of immunological disorders. From the observations resumed in this review, we can already conclude that, when a perturbation in $\mathrm{GH} / \mathrm{IGF}-1$ axis is clearly evidenced in immunodeficient individuals and when thymic function is, at 
least partially, involved in the compromised immunity, the pharmacological use of $\mathrm{GH}$ deserves to be considered.

\section{ACKNOWLEDGMENTS}

These studies are supported by the Fund of Scientific Research of Belgium (FSR, Brussels), by the Fund for Research in Industry and Agronomy (FRIA, Brussels), by the Wallonia Region (Project Reseaux 2 Senegene, $n^{\circ}$ 05/1/6192) and by an Independent Research Grant from Pfizer Europe. Hamid Kermani, MD has received a grant from the Ministry of Health and Medical Education (Islamic Republic of Iran).

\section{ABBREVIATIONS}

\begin{tabular}{|c|c|c|}
\hline AGHD & $=$ & Adult growth hormone deficiency \\
\hline $\mathrm{CD}$ & $=$ & Cluster differentiation \\
\hline $\mathrm{DN}$ & $=$ & Double-negative thymocytes \\
\hline DP & $=$ & Double-positive thymocytes \\
\hline $\mathrm{GH}$ & $=$ & Growth hormone \\
\hline GHD & $=$ & Growth hormone deficiency \\
\hline HAART & $=$ & Highly active antiretroviral therapy \\
\hline $\mathrm{MHC}$ & $=$ & Major histocompatibility complex \\
\hline RAG & $=$ & Recombination-activating enzymes \\
\hline RSS & $=$ & Recombination signal sequences \\
\hline SP & $=$ & Single positive T cells \\
\hline SjTREC & $=$ & Signal-joint TREC \\
\hline TEC & $=$ & Thymic epithelial cells \\
\hline TCR & $=$ & T-cell receptor for antigen \\
\hline TREC & $=$ & $\begin{array}{l}\text { T-cell receptor rearrangement excision } \\
\text { circles }\end{array}$ \\
\hline
\end{tabular}

\section{REFERENCES}

[1] Rothenberg, E.V.; Yui, M.A.; Telfer, J.C. T-Cell Developmental Biology. In: Fundamental Immunology $5^{\text {th }}$ ed.; Paul, W.E. Ed.; Lippincott Williams \& Wilkins; Philadelphia, 2003, pp. 259-301.

[2] Liston, A.; Nutsch, K.M.; Farr, A.G.; Lund, J.M.; Rasmussen, J.P.; Koni, P.A.; Rudensky, A.Y. Differentiation of regulatory Foxp3+ T cells in the thymic cortex. Proc. Natl. Acad. Sci. USA, 2008, 105(33), 11903-11908.

[3] Blalock, J.E. The syntax of immune-neuroendocrine communication. Immunol. Today, 1994, 15(11), 504-511.

[4] Savino, W.; Dardenne, M. Immune-neuroendocrine interactions. Immunol. Today, 1995, 16(7), 318-322.

[5] Madden, K.S.; Felten, D.L. Experimental basis for neural-immune interactions. Physiol. Rev., 1995, 75(1), 77-106.

[6] Besedovsky, H.O.; del Rey, A. Immune-neuro-endocrine interactions: facts and hypotheses. Endocr. Rev., 1996, 17(1), 64-102.

[7] Arpin, C.; Pihlgren, M.; Fraichard, A.; Aubert, D.; Samarut, J.; Chassande, O.; Marvel, J. Effects of T3R alpha 1 and T3R alpha 2 gene deletion on $\mathrm{T}$ and B lymphocyte development. J. Immunol., 2000, 164(1), 152-160.

[8] Smith, P. The effect of hypophysectomy upon the involution of the thymus in the rat. Anat. Rec., 1930, 47, 119-143.

[9] Weigent, D.A. Immunoregulatory properties of growth hormone and prolactin. Pharmacol. Ther., 1996, 69(3), 237-257.

[10] Savino, W.; Dardenne, M. Pleiotropic modulation of thymic functions by growth hormone: from physiology to therapy. Curr. Opin. Pharmacol., 2010, 10(4), 434-442.

[11] Weigent, D.A.; Blalock, J.E. Expression of growth hormone by lymphocytes. Int. Rev. Immunol., 1989, 4(3), 193-211.
[12] Venters, H.D.; Dantzer, R.; Freund, G.G.; Broussard, S.R., Kelley, K.W. Growth hormone and insulin-like growth factor as cytokines in the immune system. In Psychoneuroimmunology, $3^{\text {rd }}$ ed.; Ader, R.; Felten, D.L. Cohen, N. Eds.; Academic Press, San Diego, 2001; Vol. 1, pp 339-362.

13] Meazza, C.; Pagani, S.; Travaglino, P.; Bozzola, M. Effect of growth hormone $(\mathrm{GH})$ on the immune system. Pediatr. Endocrinol. Rev., 2004, (1 Suppl. 3), 490-495.

14] Napolitano, L.A.; Lo, J.C.; Gotway, M.B.; Mulligan, K.; Barbour, J.D.; Schmidt, D.; Grant, R.M.; Halvorsen, R.A.; Schambelan, M.; McCune, J.M. Increased thymic mass and circulating naive CD4 T cells in HIV-1-infected adults treated with growth hormone. AIDS, 2002, 16(8), 1103-1111.

15] Napolitano, L.A.; Schmidt, D.; Gotway, M.B.; Ameli, N.; Filbert E.L.; Ng, M.M.; Clor, J.L.; Epling, L.; Sinclair, E.; Baum, P.D.; Li, K.; Killian, M.L.; Bacchetti, P.; McCune, J.M. Growth hormone enhances thymic function in HIV-1-infected adults. J. Clin. Invest., 2008, 118(3), 1085-1098.

Morrhaye, G.; Kermani, H.; Legros, J.J.; Baron, F.; Beguin, Y.; Moutschen, M.; Cheynier, R.; Martens, H.J.; Geenen, V. Impact of growth hormone $(\mathrm{GH})$ deficiency and $\mathrm{GH}$ replacement upon thymus function in adult patients. PLoS One, 2009, 4(5), e5668.

Miller, J.F., The discovery of thymus function and of thymusderived lymphocytes. Immunol. Rev., 2002, 185, 7-14

Haynes, B.F.; Heinly, C.S. Early human T cell development: analysis of the human thymus at the time of initial entry of hematopoietic stem cells into the fetal thymic microenvironment. J. Exp. Med., 1995, 181(4), 1445-1458.

Larsen, W.J. Development of the Head and Neck. In: Human Embryology $1^{\text {st }}$ ed.; Larsen, W.J. Ed.; Churchill Livingstone; New York, 1993, pp. 311-340.

Blackburn, C.C.; Manley, N.R. Developing a new paradigm for thymus organogenesis. Nat. Rev. Immunol., 2004, 4(4), 278-289.

Gordon, J.; Wilson, V.A.; Blair, N.F.; Sheridan, J.; Farley, A.; Wilson, L.; Manley, N.R.; Blackburn, C.C. Functional evidence for a single endodermal origin for the thymic epithelium. Nat. Immunol., 2004, 5(5), 546-553.

Jotereau, F.; Heuze, F.; Salomon-Vie, V.; Gascan, H. Cell kinetics in the fetal mouse thymus: precursor cell input, proliferation, and emigration. J. Immunol., 1987, 138(4), 1026-1030.

Rossi, S.W.; Jenkinson, W.E.; Anderson, G.; Jenkinson, E.J. Clonal analysis reveals a common progenitor for thymic cortical and medullary epithelium. Nature, 2006, 441(7096), 988-991.

Anderson, G.; Pongracz, J.; Parnell, S.; Jenkinson, E.J. Notch ligand-bearing thymic epithelial cells initiate and sustain Notch signaling in thymocytes independently of $\mathrm{T}$ cell receptor signaling. Eur. J. Immunol., 2001, 31(11), 3349-3354.

[25] van Ewijk, W.; Shores, E.W.; Singer, A. Crosstalk in the mouse thymus. Immunol. Today, 1994, 15(5), 214-217.

[26] Ciofani, M.; Zuniga-Pflucker, J.C. The thymus as an inductive site for T lymphopoiesis. Annu. Rev. Cell. Dev. Biol., 2007, 23, $463-$ 493.

[27] Muller, S.M.; Terszowski, G.; Blum, C.; Haller, C.; Anquez, V.; Kuschert, S.; Carmeliet, P.; Augustin, H.G.; Rodewald, H.R. Gene targeting of VEGF-A in thymus epithelium disrupts thymus blood vessel architecture. Proc. Natl. Acad. Sci. USA, 2005, 102(30), 10587-10592.

[28] Gray, D.H.; Tull, D.; Ueno, T.; Seach, N.; Classon, B.J.; Chidgey, A.; McConville, M.J.; Boyd, R.L. A unique thymic fibroblast population revealed by the monoclonal antibody MTS-15. J. Immunol., 2007, 178(8), 4956-4965.

[29] Raviola, E.; Karnovsky, M.J. Evidence for a blood-thymus barrier using electron-opaque tracers. J. Exp. Med., 1972, 136(3), 466-498.

[30] Anderson, M.; Anderson, S.K.; Farr, A.G. Thymic vasculature: organizer of the medullary epithelial compartment? Int. Immunol., 2000, 12(7), 1105-1110.

[31] Scollay, R.; Smith, J.; Stauffer, V. Dynamics of early T cells: prothymocyte migration and proliferation in the adult mouse thymus. Immunol. Rev., 1986, 91, 129-157.

[32] MacDonald, H.R.; Howe, R.C.; Pedrazzini, T.; Lees, R.K.; Budd, R.C.; Schneider, R.; Liao, N.S.; Zinkernagel, R.M.; Louis, J.A.; Raulet, D.H.; Hengartner, H.; Miescher, G. T-cell lineages, repertoire selection and tolerance induction. Immunol. Rev., 1988, 104, 157-182. 
[33] Jiang, S.; Lechler, R.I.; He, X.S.; Huang, J.F. Regulatory T cells and transplantation tolerance. Hum. Immunol., 2006, 67(10), 765776.

[34] Savino, W.; Mendes-da-Cruz, D.A.; Silva, J.S.; Dardenne, M.; Cotta-de-Almeida, V. Intrathymic T-cell migration: a combinatorial interplay of extracellular matrix and chemokines? Trends Iтmиnol., 2002, 23(6), 305-313.

[35] Park, J.H.; Adoro, S.; Guinter, T.; Erman, B.; Alag, A.S.; Catalfamo, M.; Kimura, M.Y.; Cui, Y.; Lucas, P.J.; Gress, R.E.; Kubo, M.; Hennighausen, L.; Feigenbaum, L.; Singer, A. Signaling by intrathymic cytokines, not $\mathrm{T}$ cell antigen receptors, specifies CD8 lineage choice and promotes the differentiation of cytotoxic-lineage T cells. Nat. Immunol., 2010, 11(3), 257-264

[36] Douek, D.C.; McFarland, R.D.; Keiser, P.H.; Gage, E.A.; Massey, J.M.; Haynes, B.F.; Polis, M.A.; Haase, A.T.; Feinberg, M.B.; Sullivan, J.L.; Jamieson, B.D.; Zack, J.A.; Picker, L.J.; Koup, R.A. Changes in thymic function with age and during the treatment of HIV infection. Nature, 1998, 396(6712), 690-695.

[37] Poulin, J.F.; Viswanathan, M.N.; Harris, J.M.; Komanduri, K.V.; Wieder, E.; Ringuette, N.; Jenkins, M.; McCune, J.M.; Sekaly, R.P. Direct evidence for thymic function in adult humans. J. Exp. Med., 1999, 190(4), 479-486.

[38] Castermans, E.; Baron, F.; Willems, E.; Schaaf-Lafontaine, N.; Meuris, N.; Gothot, A.; Vanbellighen, J.F.; Herens, C.; Seidel, L.; Geenen, V.; Cheynier, R.; Beguin, Y. Evidence for neo-generation of $\mathrm{T}$ cells by the thymus after non-myeloablative conditioning. Haematologica, 2008, 93(2), 240-247.

[39] Geenen, V.; Poulin, J.F.; Dion, M.L.; Martens, H.; Castermans, E.; Hansenne, I.; Moutschen, M.; Sekaly, R.P.; Cheynier, R. Quantification of $\mathrm{T}$ cell receptor rearrangement excision circles to estimate thymic function: an important new tool for endocrine-immune physiology. J. Endocrinol., 2003, 176(3), 305-311.

[40] Dion, M.L.; Poulin, J.F.; Bordi, R.; Sylvestre, M.; Corsini, R.; Kettaf, N.; Dalloul, A.; Boulassel, M.R.; Debre, P.; Routy, J.P.; Grossman, Z.; Sekaly, R.P.; Cheynier, R. HIV infection rapidly induces and maintains a substantial suppression of thymocyte proliferation. Immunity, 2004, 21(6), 757-768.

[41] van den Dool, C.; de Boer, R.J. The effects of age, thymectomy, and HIV Infection on alpha and beta TCR excision circles in naive T cells. J. Immunol., 2006, 177(7), 4391-4401.

[42] Dulude, G.; Cheynier, R.; Gauchat, D.; Abdallah, A.; Kettaf, N.; Sekaly, R.P.; Gratton, S. The magnitude of thymic output is genetically determined through controlled intrathymic precursor $\mathrm{T}$ cell proliferation. J. Immunol., 2008, 181(11), 7818-7824.

[43] Dion, M.L.; Sekaly, R.P.; Cheynier, R. Estimating thymic function through quantification of T-cell receptor excision circles. Methods Mol. Biol., 2007, 380, 197-213.

[44] Leonard, W.J. Type 1 Cytokines and Interferons and Their Receptor. In: Fundamental Immunology $5^{\text {th }}$ ed.; Paul, W.E. Ed.; Lippincott Williams \& Wilkins; Philadelphia, 2003, pp. 701-747.

[45] Cosman, D.; Lyman, S.D.; Idzerda, R.L.; Beckmann, M.P.; Park, L.S.; Goodwin, R.G.; March, C.J. A new cytokine receptor superfamily. Trends Biochem. Sci., 1990, 15(7), 265-270.

[46] Heim, M.H. The Jak-STAT pathway: cytokine signalling from the receptor to the nucleus. J. Recept. Signal Transduct. Res., 1999, 19(1-4), 75-120.

[47] Tripathi, A.; Sodhi, A. Growth hormone-induced production of cytokines in murine peritoneal macrophages in vitro: role of JAK/STAT, PI3K, PKC and MAP kinases. Immunobiology, 2009, 214(6), 430-440

[48] Wang, X.; Yang, N.; Deng, L.; Li, X.; Jiang, J.; Gan, Y.; Frank, S.J. Interruption of growth hormone signaling via SHC and ERK in 3T3-F442A preadipocytes upon knockdown of insulin receptor substrate-1. Mol. Endocrinol., 2009, 23(4), 486-496.

[49] Flores-Morales, A.; Greenhalgh, C.J.; Norstedt, G.; Rico-Bautista, E. Negative regulation of growth hormone receptor signaling. Mol. Endocrinol., 2006, 20(2), 241-253.

[50] Mayo, K.E.; Miller, T.L.; DeAlmeida, V.; Zheng, J.; Godfrey, P.A. The growth-hormone-releasing hormone receptor: signal transduction, gene expression, and physiological function in growth regulation. Ann. NY Acad. Sci., 1996, 805, 184-203.

[51] Tentler, J.J.; Hadcock, J.R.; Gutierrez-Hartmann, A. Somatostatin acts by inhibiting the cyclic 3',5'-adenosine monophosphate (cAMP)/protein kinase A pathway, cAMP response elementbinding protein (CREB) phosphorylation, and CREB transcription potency. Mol. Endocrinol., 1997, 11(7), 859-866.
[52] van der Lely, A.J.; Tschop, M.; Heiman, M.L.; Ghigo, E. Biological, physiological, pathophysiological, and pharmacological aspects of ghrelin. Endocr. Rev., 2004, 25(3), 426-457.

[53] Kojima, M.; Kangawa, K. Ghrelin: structure and function. Physiol. Rev., 2005, 85(2), 495-522.

[54] Chawla, R.K.; Parks, J.S.; Rudman, D. Structural variants of human growth hormone: biochemical, genetic, and clinical aspects. Annu.Rev. Med., 1983, 34, 519-547.

[55] Maggiano, N.; Piantelli, M.; Ricci, R.; Larocca, L.M.; Capelli, A.; Ranelletti, F.O. Detection of growth hormone-producing cells in human thymus by immunohistochemistry and non-radioactive in situ hybridization. J. Histochem. Cytochem., 1994, 42(10), 13491354 .

[56] Weigent, D.A.; Blalock, J.E. The production of growth hormone by subpopulations of rat mononuclear leukocytes. Cell. Immunol., 1991, 135(1), 55-65.

[57] Guarcello, V.; Weigent, D.A.; Blalock, J.E. Growth hormone releasing hormone receptors on thymocytes and splenocytes from rats. Cell. Immunol., 1991, 136(2), 291-302.

[58] Weigent, D.A.; Blalock, J.E. Effect of the administration of growth-hormone-producing lymphocytes on weight gain and immune function in dwarf mice. Neuroimmunomodulation, 1994, 1(1), 50-58.

[59] Kooijman, R.; Malur, A.; Van Buul-Offers, S.C.; Hooghe-Peters, E.L. Growth hormone expression in murine bone marrow cells is independent of the pituitary transcription factor Pit-1. Endocrinology, 1997, 138(9), 3949-3955.

[60] Arrenbrecht, S. Specific binding of growth hormone to thymocytes. Nature, 1974, 252 (5480), 255-257.

[61] Gagnerault, M.C.; Postel-Vinay, M.C.; Dardenne, M. Expression of growth hormone receptors in murine lymphoid cells analyzed by flow cytofluorometry. Endocrinology, 1996, 137(5), 1719-1726.

[62] Mertani, H.C.; Morel, G. In situ gene expression of growth hormone $(\mathrm{GH})$ receptor and $\mathrm{GH}$ binding protein in adult male rat tissues. Mol. Cell. Endocrinol., 1995, 109(1), 47-61.

[63] Jones, J.I.; Clemmons, D.R. Insulin-like growth factors and their binding proteins: biological actions. Endocr. Rev., 1995, 16(1), 334.

[64] LeRoith, D.; Baserga, R.; Helman, L.; Roberts, C.T.Jr. Insulin-like growth factors and cancer. Ann. Intern. Med., 1995, 122(1), 54-59.

[65] Nissley, P.; Lopaczynski, W. Insulin-like growth factor receptors. Growth Factors, 1991, 5(1), 29-43.

[66] Adams, T.E.; Epa, V.C.; Garrett, T.P.; Ward, C.W. Structure and function of the type 1 insulin-like growth factor receptor. Cell. Mol. Life Sci., 2000, 57(7), 1050-1093.

[67] Bu, Y.H.; He, Y.L.; Zhou, H.D.; Peng, D.; Liu, W.; Tang, A.G.; Tang, L.L.; Xie, H.; Huang, Q.X.; Luo, X.H.; Liao, E.Y. Insulin receptor substrate 1 regulates the cellular differentiation and the matrix metalloproteinase expression of preosteoblastic cells. J. Endocrinol., 2010, 206(3), 271-277

[68] Stewart, C.E.; Rotwein, P. Growth, differentiation, and survival: multiple physiological functions for insulin-like growth factors. Physiol. Rev., 1996, 76(4), 1005-1026.

[69] Daughaday, W.H.; Rotwein, P. Insulin-like growth factors I and II Peptide, messenger ribonucleic acid and gene structures, serum, and tissue concentrations. Endocr. Rev., 1989, 10(1), 68-91

[70] Lupu, F.; Terwilliger, J.D.; Lee, K.; Segre, G.V.; Efstratiadis, A. Roles of growth hormone and insulin-like growth factor 1 in mouse postnatal growth. Dev. Biol., 2001, 229(1), 141-162.

[71] Hwa, V.; Oh, Y.; Rosenfeld, R.G. The insulin-like growth factorbinding protein (IGFBP) superfamily. Endocr. Rev., 1999, 20(6), 761-787.

[72] Yakar, S.; Liu, J.L.; Stannard, B.; Butler, A.; Accili, D.; Sauer, B.; LeRoith, D., Normal growth and development in the absence of hepatic insulin-like growth factor I. Proc. Natl. Acad. Sci. USA, 1999, 96(13), 7324-7329.

[73] Kecha, O.; Brilot, F.; Martens, H.; Franchimont, N.; Renard, C.; Greimers, R.; Defresne, M.P.; Winkler, R.; Geenen, V. Involvement of insulin-like growth factors in early $\mathrm{T}$ cell development: a study using fetal thymic organ cultures. Endocrinology, 2000, 141(3), 1209-1217.

[74] Verland, S.; Gammeltoft, S. Functional receptors for insulin-like growth factors I and II in rat thymocytes and mouse thymoma cells. Mol. Cell. Endocrinol., 1989, 67(2-3), 207-216.

[75] Kelley, K.W.; Meier, W.A.; Minshall, C.; Schacher, D.H.; Liu, Q.; VanHoy, R.; Burgess, W.; Dantzer, R. Insulin growth factor-I in- 
hibits apoptosis in hematopoietic progenitor cells. Implications in thymic aging. Ann. NY Acad. Sci., 1998, 840, 518-524.

[76] Beschorner, W.E.; Divic, J.; Pulido, H.; Yao, X.; Kenworthy, P.; Bruce, G. Enhancement of thymic recovery after cyclosporine by recombinant human growth hormone and insulin-like growth factor I. Transplantation, 1991, 52(5), 879-884.

[77] Hinton, P.S.; Peterson, C.A.; Dahly, E.M.; Ney, D.M. IGF-I alters lymphocyte survival and regeneration in thymus and spleen after dexamethasone treatment. Am. J. Physiol., 1998, 274(4 Pt 2), R912-920.

[78] Kelley, K.W.; Brief, S.; Westly, H.J.; Novakofski, J.; Bechtel, P.J.; Simon, J.; Walker, E.B. GH3 pituitary adenoma cells can reverse thymic aging in rats. Proc. Natl. Acad. Sci. USA, 1986, 83(15), 5663-5667.

[79] Clark, R.; Strasser, J.; McCabe, S.; Robbins, K.; Jardieu, P. Insulinlike growth factor-1 stimulation of lymphopoiesis. J. Clin. Invest., 1993, $92(2), 540-548$.

[80] van Buul-Offers, S.C.; Kooijman, R. The role of growth hormone and insulin-like growth factors in the immune system. Cell. Mol. Life Sci., 1998, 54(10), 1083-1094.

[81] Chu, Y.W.; Schmitz, S.; Choudhury, B.; Telford, W.; Kapoor, V.; Garfield, S.; Howe, D.; Gress, R.E. Exogenous insulin-like growth factor 1 enhances thymopoiesis predominantly through thymic epithelial cell expansion. Blood, 2008, 112(7), 2836-2846.

[82] Zhou, R.; Flaswinkel, H.; Schneider, M.R.; Lahm, H.; Hoeflich, A.; Wanke, R.; Wolf, E. Insulin-like growth factor-binding protein-4 inhibits growth of the thymus in transgenic mice. J. Mol. Endocrinol., 2004, 32(2), 349-364.

[83] Sabharwal, P.; Varma, S. Growth hormone synthesized and secreted by human thymocytes acts via insulin-like growth factor I as an autocrine and paracrine growth factor. J. Clin. Endocrinol. Metab., 1996, 81(7), 2663-2669.

[84] Yamada, M.; Hato, F.; Kinoshita, Y.; Tominaga, K.; Tsuji, Y. The indirect participation of growth hormone in the thymocyte proliferation system. Cell Mol. Biol. (Noisy-le-grand), 1994, 40(2), 111121.

[85] Timsit, J.; Savino, W.; Safieh, B.; Chanson, P.; Gagnerault, M.C.; Bach, J.F.; Dardenne, M. Growth hormone and insulin-like growth factor-I stimulate hormonal function and proliferation of thymic epithelial cells. J. Clin. Endocrinol. Metab., 1992, 75(1), 183-188.

[86] Tsuji, Y.; Kinoshita, Y.; Hato, F.; Tominaga, K.; Yoshida, K. The in vitro proliferation of thymus epithelial cells stimulated with growth hormone and insulin-like growth factor-I. Cell Mol. Biol. (Noisy-le-grand), 1994, 40(8), 1135-1142.

[87] Aiuti, A.; Tavian, M.; Cipponi, A.; Ficara, F.; Zappone, E.; Hoxie, J.; Peault, B.; Bordignon, C. Expression of CXCR4, the receptor for stromal cell-derived factor-1 on fetal and adult human lymphohematopoietic progenitors. Eur. J. Immunol., 1999, 29(6), 18231831.

[88] Smaniotto, S.; de Mello-Coelho, V.; Villa-Verde, D.M.; Pleau, J.M.; Postel-Vinay, M. C.; Dardenne, M.; Savino, W. Growth hormone modulates thymocyte development in vivo through a combined action of laminin and $\mathrm{CXC}$ chemokine ligand 12. Endocrinology, 2005, 146(7), 3005-3017.

[89] Golde, D.W.; Bersch, N.; Li, C.H. Growth hormone: speciesspecific stimulation of erythropoiesis in vitro. Science, 1977, 196(4294), 1112-1113.

[90] Duquesnoy, R.J.; Pedersen, G. Immunologic and hematologic deficiencies of the hypopituitary dwarf mouse. In: Immunologic Defects in Laboratory Animals; Gershwin, M.E., Merchant, B. Eds.; Plenum; New York, 1981, Vol. 1, pp 309-324.

[91] Merchav, S.; Tatarsky, I.; Hochberg, Z. Enhancement of human granulopoiesis in vitro by biosynthetic insulin-like growth factor $\mathrm{I} /$ somatomedin $\mathrm{C}$ and human growth hormone. J. Clin. Invest., 1988, 81(3), 791-797.

[92] Murphy, W.J.; Tsarfaty, G.; Longo, D.L. Growth hormone exerts hematopoietic growth-promoting effects in vivo and partially counteracts the myelosuppressive effects of azidothymidine. Blood, 1992, 80(6), 1443-1447.

[93] Murphy, W.J.; Durum, S. K.; Longo, D.L. Differential effects of growth hormone and prolactin on murine $\mathrm{T}$ cell development and function. J. Exp. Med., 1993, 178(1), 231-236.

[94] Dorshkind, K.; Horseman, N.D., Anterior pituitary hormones, stress, and immune system homeostasis. Bioessays, 2001, 23(3), 288-294.
[95] Taub, D.D.; Tsarfaty, G.; Lloyd, A.R.; Durum, S.K.; Longo, D.L.; Murphy, W.J. Growth hormone promotes human T cell adhesion and migration to both human and murine matrix proteins in vitro and directly promotes xenogeneic engraftment. J. Clin. Invest., 1994, 94(1), 293-300.

[96] Savino, W.; de Mello-Coelho, V.; Dardenne, M. Control of the thymic microenvironment by growth hormone/insulin-like growth factor-I-mediated circuits. Neuroimmunomodulation, 1995, 2(6), 313-318.

[97] de Mello-Coelho, V.; Villa-Verde, D.M.; Dardenne, M.; Savino, W. Pituitary hormones modulate cell-cell interactions between thymocytes and thymic epithelial cells. J. Neuroimmunol., 1997, 76(1-2), 39-49.

[98] Montecino-Rodriguez, E.; Clark, R.; Dorshkind, K. Effects of insulin-like growth factor administration and bone marrow transplantation on thymopoiesis in aged mice. Endocrinology, 1998, 139(10), 4120-4126.

[99] Tseng, Y.H.; Kessler, M.A.; Schuler, L.A. Regulation of interleukin (IL)-1alpha, IL-1beta, and IL-6 expression by growth hormone and prolactin in bovine thymic stromal cells. Mol. Cell. Endocrinol., 1997, 128(1-2), 117-127.

[100] Goya, R.G.; Gagnerault, M.C.; De Moraes, M.C.; Savino, W.; Dardenne, M. In vivo effects of growth hormone on thymus function in aging mice. Brain Behav. Immun., 1992, 6(4), 341-354.

[101] Dorshkind, K.; Horseman, N.D. The roles of prolactin, growth hormone, insulin-like growth factor-I, and thyroid hormones in lymphocyte development and function: insights from genetic models of hormone and hormone receptor deficiency. Endocr. Rev., 2000, $21(3), 292-312$.

[102] Auernhammer, C.J.; Strasburger, C.J. Effects of growth hormone and insulin-like growth factor I on the immune system. Eur. J. Endocrinol., 1995, 133(6), 635-645.

[103] de Mello-Coelho, V.; Gagnerault, M.C.; Souberbielle, J.C.; Strasburger, C.J.; Savino, W.; Dardenne, M.; Postel-Vinay, M.C. Growth hormone and its receptor are expressed in human thymic cells. Endocrinology, 1998, 139(9), 3837-3842.

[104] Kooijman, R.; Scholtens, L.E.; Rijkers, G.T.; Zegers, B.J. Type I insulin-like growth factor receptor expression in different developmental stages of human thymocytes. J. Endocrinol., 1995, 147(2), 203-209.

[105] Baxter, J.B.; Blalock, J.E.; Weigent, D.A. Expression of immunoreactive growth hormone in leukocytes in vivo. J. Neuroimmunol., 1991, 33(1), 43-54.

[106] Han, Y.; Leaman, D.W.; Watling, D.; Rogers, N.C.; Groner, B.; Kerr, I.M.; Wood, W.I.; Stark, G.R. Participation of JAK and STAT proteins in growth hormone-induced signaling. J. Biol. Chem., 1996, 271(10), 5947-5952.

[107] Savino, W.; Postel-Vinay, M.C.; Smaniotto, S.; Dardenne, M. The thymus gland: a target organ for growth hormone. Scand. J. Immunol., 2002, 55(5), 442-452.

[108] Froesch, E.R.; Hussain, M. Recombinant human insulin-like growth factor-I: a therapeutic challenge for diabetes mellitus. Diabetologia, 1994, 37(Suppl. 2), S179-185.

[109] Kecha, O.; Martens, H.; Franchimont, N.; Achour, I.; HazeeHagelstein, M.T.; Charlet-Renard, C.; Geenen, V.; Winkler, R. Characterization of the insulin-like growth factor axis in the human thymus. J. Neuroendocrinol., 1999, 11(6), 435-440.

[110] Rosenfeld, R.G.; Rosenbloom, A.L.; Guevara-Aguirre, J. Growth hormone $(\mathrm{GH})$ insensitivity due to primary $\mathrm{GH}$ receptor deficiency. Endocr. Rev., 1994, 15(3), 369-390.

[111] Benini, S.; Manara, M.C.; Cerisano, V.; Perdichizzi, S.; Strammiello, R.; Serra, M.; Picci, P.; Scotlandi, K. Contribution of MEK/MAPK and PI3-K signaling pathway to the malignant behavior of Ewing's sarcoma cells: therapeutic prospects. Int. J. Cancer, 2004, 108(3), 358-366.

[112] de Mello Coelho, V.; Villa-Verde, D.M.; Farias-de-Oliveira, D.A.; de Brito, J.M.; Dardenne, M.; Savino, W. Functional insulin-like growth factor-1/insulin-like growth factor-1 receptor-mediated circuit in human and murine thymic epithelial cells. Neuroendocrinology, 2002, 75(2), 139-150.

[113] Sivan, B.; Lilos, P.; Laron, Z. Effects of insulin-like growth factor-I deficiency and replacement therapy on the hematopoietic system in patients with Laron syndrome (primary growth hormone insensitivity). J. Pediatr. Endocrinol. Metab., 2003, 16(4), 509-520.

[114] Christ, E.R.; Cummings, M.H.; Westwood, N.B.; Sawyer, B.M.; Pearson, T.C.; Sonksen, P.H.; Russell-Jones, D.L. The importance 
of growth hormone in the regulation of erythropoiesis, red cell mass, and plasma volume in adults with growth hormone deficiency. J. Clin. Endocrinol. Metab., 1997, 82(9), 2985-2990.

[115] Huang, J.; Durum, S.K.; Muegge, K. Cutting edge: histone acetylation and recombination at the TCR gamma locus follows IL-7 induction. J. Immunol., 2001, 167(11), 6073-6077.

[116] Aspinall, R. T cell development, ageing and Interleukin-7. Mech. Ageing Dev., 2006, 127(6), 572-578.

[117] Bazzoni, N.; Ambrosi, B.; Arosio, M.; Barbareschi, M.; Losa, M.; Faglia, G. Acromegaly and thymic hyperplasia: a case report. $J$. Endocrinol. Invest., 1990, 13(11), 931-935.

[118] Taub, D.D.; Longo, D.L. Insights into thymic aging and regeneration. Immunol. Rev., 2005, 205, 72-93.

[119] Pfister, G.; Savino, W. Can the immune system still be efficient in the elderly? An immunological and immunoendocrine therapeutic perspective. Neuroimmunomodulation, 2008, 15(4-6), 351-364.

[120] Koo, G.C.; Huang, C.; Camacho, R.; Trainor, C.; Blake, J. T.; Sirotina-Meisher, A.; Schleim, K.D.; Wu, T.J.; Cheng, K.; Nargund, R.; McKissick, G. Immune enhancing effect of a growth hormone secretagogue. J. Immunol., 2001, 166(6), 4195-4201.

[121] Dixit, V.D.; Yang, H.; Sun, Y.; Weeraratna, A.T.; Youm, Y.H.; Smith, R.G.; Taub, D.D. Ghrelin promotes thymopoiesis during aging. J. Clin. Invest., 2007, 117(10), 2778-2790.

[122] Spadoni, G.L.; Rossi, P.; Ragno, W.; Galli, E.; Cianfarani, S.; Galasso, C.; Boscherini, B. Immune function in growth hormonedeficient children treated with biosynthetic growth hormone. Acta Paediatr. Scand., 1991, 80(1), 75-79.

[123] Dixit, V.D.; Schaffer, E.M.; Pyle, R.S.; Collins, G.D.; Sakthivel, S.K.; Palaniappan, R.; Lillard, J.W. Jr.; Taub, D.D. Ghrelin inhibits leptin- and activation-induced proinflammatory cytokine expression by human monocytes and T cells. J. Clin. Invest., 2004, 114(1), 57-66.

[124] Haynes, B.F.; Hale, L.P.; Weinhold, K.J., Patel, D.D.; Liao, H.X.; Bressler, P.B.; Jones, D.M.; Demarest, J.F.; Gebhard-Mitchell, K. Haase, A.T.; Bartlett, J.A. Analysis of the adult thymus in reconstitution of T lymphocytes in HIV-1 infection. J. Clin. Invest., 1999 103(4), 453-460.

[125] Bandera, A.; Ferrario, G.; Saresella, M.; Marventano, I.; Soria, A.; Zanini, F.; Sabbatini, F.; Airoldi, M.; Marchetti, G.; Franzetti, F.; Trabattoni, D.; Clerici, M.; Gori, A. CD4+ T cell depletion, immune activation and increased production of regulatory $\mathrm{T}$ cells in the thymus of hiv-infected individuals. PLoS One, 2010, 5, e10788.

[126] Mallewa, J.E.; Wilkins, E.; Vilar, J.; Mallewa, M.; Doran, D.; Back, D.; Pirmohamed, M. HIV-associated lipodystrophy: A review of underlying mechanisms and therapeutic options. J. Antimicrob. Chemother., 2008, 62(4), 648-660.

[127] Zirilli, L.; Orlando, G.; Diazzi, C.; Squillace, N.; Carani, C.; Guaraldi, G.; Rochira, V. Hypopituitarism and hiv-infection: A new comorbidity in the HAART era? J. Endocrinol. Invest., 2008, 31(9s), 33-38.

[128] Nguyen, B.Y.; Clerici, M.; Venzon, D.J.; Bauza, S.; Murphy, W.J.; Longo, D.L.; Baseler, M.; Gesundheit, N.; Broder, S.; Shearer, G.; Yarchoan, R. Pilot study of the immunologic effects of recombi- nant human growth hormone and recombinant insulin-like growth factor in HIV-infected patients. AIDS, 1998, 12(8), 895-904.

[129] Vigano, A.; Saresella, M.; Trabattoni, D.; Giacomet, V.; di Natale, B.; Merlo, M.; Venuto, A.; Villa, M.L.; Vanzulli, S.; Ferrante, P. Clerici, M. Growth hormone in T-lymphocyte thymic and postthymic development: A study in HIV-infected children. J. Pediatr., 2004, 145(4), 542-548.

[130] Redelman, D.; Welniak, L.A.; Taub, D.; Murphy, W.J. Neuroendocrine hormones such as growth hormone and prolactin are integral members of the immunological cytokine network. Cell. Immunol., 2008, 252(1-2), 111-121.

[131] Verinaud, L.; Da Cruz-Hofling, M.A. Sakurada, J.K.; Rangel, H.A.; Vassallo, J.; Wakelin, D.; Sewell, H.F.; Camargo, I.J. Immunodepression induced by trypanosoma cruzi and mouse hepatitis virus type 3 is associated with thymus apoptosis. Clin. Diagn. Lab. Immunol., 1998, 5(2), 186-191.

[132] Savino, W. The thymus is a common organ target for infectious diseases. PLoS Pathog., 2006, 2 , e62.

[133] Correa-de-Santana, E.; Paez-Pereda, M.; Theodoropoulou, M.; Kenji Nihei, O.; Gruebler, Y.; Bozza, M.; Arzt. E.; Villa-Verde, D.M.; Renner, U.; Stalla, J.; Stalla, G.K.; Savino, W. Hypothalamus-pituitary-adrenal axis during trypanosoma cruzi acute infection in mice. J. Neuroimmunol., 2006, 173(1-2), 12-22.

[134] Correa-de-Santana, E.; Paez-Pereda, M.; Theodoropoulou, M.; Renner, U.; Stalla, J.; Stalla, G.K.; Savino, W. Modulation of growth hormone and prolactin secretion in T. cruzi-infected mammosomatotrophic cells. Neuroimmunomodulation, 2009, 16(3), 208-212.

[135] Frare, E.O.; Santello, F.H.; Caetano, L.C.; Caldeira, J.C.; Toldo, M.P.; Prado, J.C.Jr. Growth hormones therapy in immune response against Trypanosoma cruzi. Res. Vet. Sci., 2010, 88(2), 273-278.

[136] Lemos ,E.M.; Reis, D.; Adad, S.J.; Silva, G.C.; Crema, E.; CorreaOliveira, R. Decreased CD4+ circulating T lymphocytes in patients with gastrointestinal chagas disease. Clin. Immunol. Immunopathol., 1998, 88(2), 150-155.

[137] Mendes-da-Cruz, D.A.; Silva, J.S.; Cotta-de-Almeida, V.; Savino, W. Altered thymocyte migration during experimental acute trypanosoma cruzi infection: Combined role of fibronectin and the chemokines CXCL12 and CCL4. Eur. J. Immunol., 2006, 36,14861493.

[138] Mendes-da-Cruz, D.A.; de Meis, J.; Cotta-de-Almeida, V.; Savino, W. Experimental trypanosoma cruzi infection alters the shaping of the central and peripheral t-cell repertoire. Microbes Infect., 2003, $5,825-832$

[139] Fernandez-Mestre, M.T.; Jaraquemada, D.; Bruno, R.E.; Caro, J.; Layrisse, Z. Analysis of the t-cell receptor beta-chain variableregion (Vbeta) repertoire in chronic human chagas' disease. Tissue Antigens, 2002, 60, 10-15.

[140] Costa, R.P.; Gollob, K.J.; Fonseca, L.L.; Rocha, M.O.; Chaves, A.C.; Medrano-Mercado, N.; Araujo-Jorge, T.C.; Antas, P.R., Colley, D.G.; Correa-Oliveira, R.; Gazzinelli, G., Carvalho-Parra, J.; Dutra, W.O. T-cell repertoire analysis in acute and chronic human chagas' disease: Differential frequencies of Vbeta5 expressing $\mathrm{T}$ cells. Scand. J. Immunol., 2000, 51, 511-519. 